Iwona Słomak (i) https://orcid.org/0000-0002-6940-9520

University of Silesia in Katowice

iwona.slomak[at]us.edu.pl

\title{
Military Themes in Selected Eighteenth-Century Prayer Books in Relation to the Emblem Tradition*
}

\begin{abstract}
This paper was inspired by the lack of studies that would show examples of military-erotic symbols in religious literature associated with the emblem tradition. The works discussed here, namely prayer books by Andrzej Gabriel Kasperowicz, anonymous Atak niebieskiej twierdzy [The attack of the heavens or The attack into the fortress of heavens] and Wojsko serdecznych afektów [The army of heartfelt affections] by Hieronim Falęcki, retain high formal and semantic discipline; as a result, they are examples of interesting phenomena of Baroque culture.

In the first part of the study, Słomak presents three prayer books in which the concept is based on an analogy with the organisation of the army of Christ. In the second part, she presents a book in which the theme of war is combined with the theme of "holy erotica". In part three, she discusses a print whose composition refers to the structure of military detachments. It is conceived as a collection of "affections" whose task is "to conquer" heaven and the hearts of readers. Characteristically, the formula of the discussed books will be understandable only if we reconstruct their
\end{abstract}

* Publication of this paper was financed by the Ministry of Science and Higher Education of the Republic of Poland under the grant 643/P-DUN/2018. Polish version: I. Słomak, "Militaria w wybranych modlitewnikach XVIII wieku - wobec tradycji emblematycznej”, Terminus 14 (2012), issue 25, pp. 69-84. 
reference to the popular allegorical images (to be found in the collections of emblems, in many treatises on religious themes or in descriptions of the great ceremonies of that era); therefore, it is necessary to take into account the emblematic model that clearly influenced their final shape.

Keywords: prayer books, emblems, militaria and "holy erotica", Baroque culture

So far, there have been several important studies on military-religious themes in the old-Polish literature. After valuable studies by Janusz Tazbir, Stefan Herman, Jacek Sokolski, and Jan Malicki, the most extensive one and with rich bibliography, which also includes important European sources, is a dissertation by Mirosław Lenart. ${ }^{1}$ In general, however, scholars omitted prayer books discussed in this paper (except for Wojsko serdecznych afektów by Hieronim Falęcki, mentioned in Lenart's study ${ }^{2}$ ) that demanded contextualisation and functionalisation of the concepts and images present in them, which belonged to the field of militaria. All these prayer books are rooted in the era's battle-religious imaginarium, in this case shaped, among other things, according to the specificity of the sensitivity and imagination of the Carmelite environment, to which they are associated to varying degrees. At the same time, the selected works (as well as

${ }^{1}$ J. Tazbir, Polskie przedmurze chrześcijańskiej Europy. Mity a rzeczywistość historyczna, Warsaw 1987 and a later one, slightly ammended-J. Tazbir, Polska przedmurzem Europy, Warsaw 2004; S. Herman, Wojna i żolnierz w okresie kontrreformacji (do roku 1648). Szkice z dziejów literatury polskiej i obcej, Zielona Góra 1983; J. Sokolski, "Certamen spirituale. Staropolskie poematy alegoryczne o wojnie duchownej”, Prace Literackie 24 (1983), pp. 45-84; J. Malicki, "Wacława Potockiego Rozbój duchowny", in J. Malicki, Legat wieku rycerskiego. Studia staropolskie dawne i nowe, Katowice 2006, pp. 209-233; M. Lenart, Miles pius et iustus. Żotnierz chrześcijański katolickiej wiary w kulturze i piśmiennictwie dawnej Rzeczypospolitej (XVI-XVIII wiek), Warsaw 2009.

${ }^{2}$ Old texts have been edited in accordance with the rules adopted for type B texts (Zasady wydawania tekstów staropolskich. Projekt, ed. J. Woronczak, Wrocław 1955, pp. 88-100). 
a number of others whose discussion goes beyond the scope of the present study) testify to the strong influence of the emblematic tradition on devotional literature. The latter is consequently a multidimensional discipline, both in terms of form and content, which-in the case of collections that are often multi-genre, gathering prayers for different times of the day and year, also marginalised in the research on the art of the epoch-we might not have expected.

\section{Prayer books of Andrzej Gabriel Kasperowicz (1717-1788)}

Father Kasperowicz (Kasparowicz), a preacher in Lviv, as well as a confessor and ordinary of the Benedictine Sisters and a protonotary apostolic (Estr. XIX, 166-167 ${ }^{3}$ ), was the author of several printed prayer books, including three works published almost simultaneously by the printing house of Discalced Carmelite Friars in Berdyczów: Obóz uszykowany wojsk niebieskich najjaśniejszej Królowy nieba i ziemi przy cudownym i ukoronowanym obrazie Jej, w fortecy berdyczowskiej mieszkającej, asystujacy. To jest oficjum albo godzinki na wszystkie uroczystości aniołów świętych [The ordered camp of the army of heaven that accompanies miraculous coronated painting of its queen, the brightest monarchess of heaven and earth, who resides in the Berdyczów Fortress, or the liturgy of hours on all holidays of saint angels] (Berdyczów 1769, 1770) (Estr. XIX, 166; XXIII, 19; Estreicher does not record the second edition ${ }^{4}$ ); Monarchini nieba i ziemi najświętsza, Maryja Panna w cudownym i ukoronowanym

3 The abbreviation Estr. refers to the Electronic Database of Estreicher's Bibliography (EBBE), available online at www.estreicher.uj.edu.pl (accessed on 1 Jan. 2011).

${ }^{4}$ See B. J. Wanat OCD, Drukarnia Karmelu Fortecy N.M.P. w Berdyczowie. Działalność wydawnicza i poligraficzna karmelitów bosych w Berdyczowie na Ukrainie, Cracow 2002, p. 80. 
obrazie w fortecy berdyczowskiej pierwszymi wodzami pułków Kościoła wojującego otoczona, to jest godzinki na wszystkie uroczystości świętych fundatorów zakonów różnych [The monarchess of heaven and earth, Holy Mary in the miraculous and coronated painting in the Berdyczów Fortress surrounded by the leading commanders of the regiments of the militant church, or the liturgy of hours on all holidays of the founders of various orders] (Berdyczów 1769, Estr. XXIII, 19); Ogród zamknięty liliami niewinności panieńskiej ozdobiony, pod strażą Królowy Panieńskiej będący. To jest godzinki ... z przydatkiem siedm psalmów o męce Pańskiej ... modlitwę i akty niektóre w sobie zamykajacy [A closed garden decorated with the lilies of maidenly innocence, protected by the Holy Queen, or the liturgy of hours with seven psalms on the passion of Christ as well as prayers and aspirations] (Berdyczów 1770, Estr. XIX, 166-167). ${ }^{5}$ These prints were often co-bound with other works of Kasperowicz. ${ }^{6}$ The relative order of the listed items, which are genre-homogeneous (except for part containing the Psalms), is determined by the rhythm in which they become valid as a reading-this rhythm is determined by the content of each element and consistent with the festive order. Strong compositional bonds also appear thanks to the metaphors-allegories in the headlines, which focus the reader's attention on the analogy between a collection of prayers and the organisation of a military camp, or rather military "assistance". Here one should refer to the specificity of this function of the army. In the times of Jędrzej Kitowicz, various "pompous acts"7 were performed by hussar and armoured cavalry units (Pl. choragwie) - the former maintained for this purpose only. They accompanied "the lord's entering upon his office as starosta

5 These prints are briefly mentioned by A. Litwornia, "Samsonowy oręż ojca Gaudentego", in Świt i zmierzch baroku, ed. M. Hanusiewicz, J. Dąbkowska, and A. Karpiński, Lublin 2002, p. 457.

${ }^{6}$ I use the adligat of the Jagiellonian Library, which contains the three titles mentioned above, shelf mark 42289-42291 I Mag. St. Dr.

7 J. Kitowicz, Opis obyczajów za panowania Augusta III, ed. R. Pollak, Wrocław 1970, p. 288. 
or voivode, or a funeral; . . the former and the latter also assisted during coronations of miraculous paintings". The author of Opis obyczajów [Description of Customs] devotes much attention to the detailed description of the appearance of the riders, dressed and armed uniformly and in accordance with their charge, in colourful costumes with decorations (leopard fur, ostrich feathers, golden and silver sashes) and parade armour, riding select horses, parading in a set order. ${ }^{9}$ Despite the variety of contrasting colours of the garments, which in turn served as a background for the shiny elements of the armour and numerous ornaments, the parade unit was a hierarchised whole, reflecting a certain general order characteristic of other military formations of that time. Similarly, the Kasperowicz's texts written for the liturgy of the hours, each of which is dedicated to a different patron, are very regular, which is a consequence of following the genre model. According to tradition, the seven parts of the Divine Office (Lauds, Prime, Terce, Sext, None, Vespers, Compline) correspond to the canonical hours. The individual parts consist of invocation, hymn, antiphon, and prayer. ${ }^{10}$ Repeatability results in a series of symmetries which, without reducing the diversity of content, contribute to the inner order. Attention should also be paid to the addressees of these texts. The hours of Obóz uszykowany wojsk niebieskich are devoted to the figures of the "angelic army", "heavenly heroes", "guards" and "defenders"; in Monarchini nieba i ziemi and Ogród zamknięty-male and female saints of the Catholic Church respectively; all of them are asked for care and mediacy.

For comparison, we should mention here another example of a work from the epoch that refers to the same tradition. In 1635, a booklet by Albrecht Stanisław Radziwiłł was published: Dyskurs nabożny z kilku słów wzięty o wysławieniu najświętszej Panny Bogarodzicy Maryjej.

\footnotetext{
8 Ibid., p. 297.

9 Ibid., pp. 297-307.

10 J. Kopeć, "Godzinki”, in Encyklopedia katolicka, vol. 5, Lublin 1989, pp. 1238-
} 1239. 
Świeckim, zakonnym, kaznodziejom potrzebny ${ }^{11}$ [A Devotional Discourse Composed of Several Words about the Fame of the Virgin Mary. For the Laics, Monks, and Clergymen] (Estr. VIII, 214; 217; 286), which provides a comment on the pericope Pulchra es, amica mea, suavis et decora sicut Jerusalem, terribilis ut castrorum acies ordinata (Song 6:3), ${ }^{12}$ in translation rendered as: "You are beautiful and ornate, Daughter of Jerusalem, terrible as an array of well-ordered troops" ${ }^{13}$ The author refers to these words directly in chapter six, in which he compares Mary to an army standing in formation. In the description of a series of analogies between troops ready for a battle and the followers of Holy Mary, and then her life and attributes, there is also a place for referring to Mary as the hetman in charge of the "colonels" and "cavalry captains" (patriarchs, prophets, apostles, and followers). ${ }^{14}$ There is an observable analogy between the addressees of individual prayers in Kasperowicz's breviaries and the ideal army of Mary or Christ, who differ in details (according to Radziwiłl, they had different colours of banners ${ }^{15}$ ), although they form a compact corps, serving under one commander. The affective tone of the service corresponds to the possible effect that the splendour of the military assistance had on the participant of the show. "The display of the hussars' and armoured units was really worth seeing ...", wrote Kitowicz, "It will be no exaggeration if I say that no monarch in the world has ever had anything so impressive". ${ }^{16}$

Each of the prints in question is also strongly connected with a specific image, which in turn requires a mention of the miraculous

${ }_{11}$ A. S. Radziwiłł, Dyskurs nabożny. .., Cracow 1650. Jagiellonian Library 37105 I Mag St. Dr. The work is mentioned by M. Lenart, Miles pius et iustus, pp. 227-228.

${ }_{12}$ Latin biblical quotes cited as in: Biblia sacra vulgatae editionis ... edita Romae ex Typographia Apostolica Vaticana MDXCIII. Edito nova auctoritate summi pontifices Leonis XII excusa, Frankfurt: typis et sumptibus Andreae, 1826.

${ }_{13}^{13}$ Radziwiłł, Dyskurs nabożny, p. 1.

${ }_{14}$ Ibid., pp. 277-279.

${ }^{15}$ Ibid., pp. 292-293.

${ }_{16}$ Kitowicz, Opis obyczajów, p. 300. 
painting of Holy Mary of Berdyczów. ${ }^{17}$ The painting was donated to the Carmelite Friars by Janusz of Łochojsko Tyszkiewicz, the Voivode of Kiev and the Starost of Zhytomyr and Sniatyn, the founder of the Carmelite monastery and church in Berdyczów, who for this purpose gave the monks the castle buildings together with the square, village and the income secured on the voivode's estate. The inauguration of monastic life in Berdyczów began in 1642, but in the following century the Carmelites left their monastery many times. During the Cossack and Tartar wars (1648-1649) it was partially destroyed. After its restoration (from 1663), Tyszkiewicz's heirs claimed the property, invaded the monastery by force of arms, plundered and seized it (1684). The property was returned to the Carmelites after a long trial in the second decade of the eighteenth century, when the destroyed church and monastery were reconstructed, and the monastery was turned into a defensive fortress, armed with sixty guns and maintaining a permanent defensive garrison. The miraculous painting returned to the Berdyczów church, which it had left earlier for many years, and the Roman General Definitory allowed the monastery to maintain a military crew as a guard. The guard that stationed at the painting and in the garrison of the "fortress of Holy Mary", as the Berdyczów fortress was called, is a tableau vivant, which is in connection with the allegory of the "ordered camp", the "first regiment leaders of the militant Church", as well as the "garden under the guardianship of the Virgin Queen". Another tableau vivant is described in an account that survived to this day: due to numerous healings and graces bestowed by the miraculous icon, efforts were made to coronate the painting. The ceremony took place in 1756 and the crowns of gold were donated by Pope Benedict XIV. The commemorative work published a decade later (Ozdoba i obrona ukrainskich krajów, przecudowna w berdyczowskim

${ }_{17}$ B. J. Wanat writes in detail about the history of the painting and the whole Berdyczów Carmelite monastery, providing the source bibliography: see B. J. Wanat OCD, Zakon Karmelitów Bosych w Polsce. Klasztory karmelitów i karmelitanek bosych 1605-1975, Cracow 1979, pp. 377-382. 
obrazie Maryja ... ukoronowana ... [The Adornment and Protection of Ukrainian Lands, Holy Mary in the Miraculous Coronated Painting in Berdyczów $]^{18}$ ) includes a comprehensive description of bringing the crowns to the church and eight-day coronation ceremonies that were conducted three years later, ${ }^{19}$ accompanied by speeches, sermons, disputes, frequent cannon salutes, and illuminations. In order to accommodate the faithful, a magnificent wooden "shed" with 20,000 seats and decorated with paintings was built outside the town. On the way from the "shed" to the church, eight triumphant gates were erected. The seventh (fig. 1), most impressive one, was supposed to represent the Berdyczów fortress - the crowned image was in a "revetment made of arms"; six "geniuses" with broadswords stood on the ramparts. On the reverse of the title page of the second part of Ozdoba i obrona ukraińskich krajów (fig. 2), the miraculous painting is depicted, and below it a procession from the "shed" to the church with a military assist in the foreground.

In Kasperowicz's works these live processions around the "Monarchess of heaven and earth" are replaced by the "arranged" prayers. The devotional appeals formed in analogy to the military procession are addressed to angels and saints as intermediaries; at the same time, each of the prayers exposes these figures. A rotation of the earthly and heavenly armies is depicted here. The "units" in the breviary are the equivalent of the select "heavenly knights"-angels and saints who, in the literature of the epoch, constitute the proper personal models for earthly "soldiers of Christ". The "heavenly hosts" are ontologically established in many places in the Old and New Testaments, and at the same time the earthly military can serve as a model for their organisation, whose rituals, such as vows, taking patrons, using spells and magical objects, include them in the sphere of sacrum. ${ }^{20}$ In this particular case, however, the main inspiration is

18 Berdyczów 1767. Jagiellonian Library 58895 Mag. St. Dr.

19 Between 16 July 1756, the actual day of the coronation, and 23 July, the octave of the holiday. The ceremonial services began even earlier, on 13 July.

${ }^{20}$ Publius Flavius Vegetius Renatus (the second half of the fourth century), the author of a compendium of Roman warfare art (Epitoma rei militari), which 


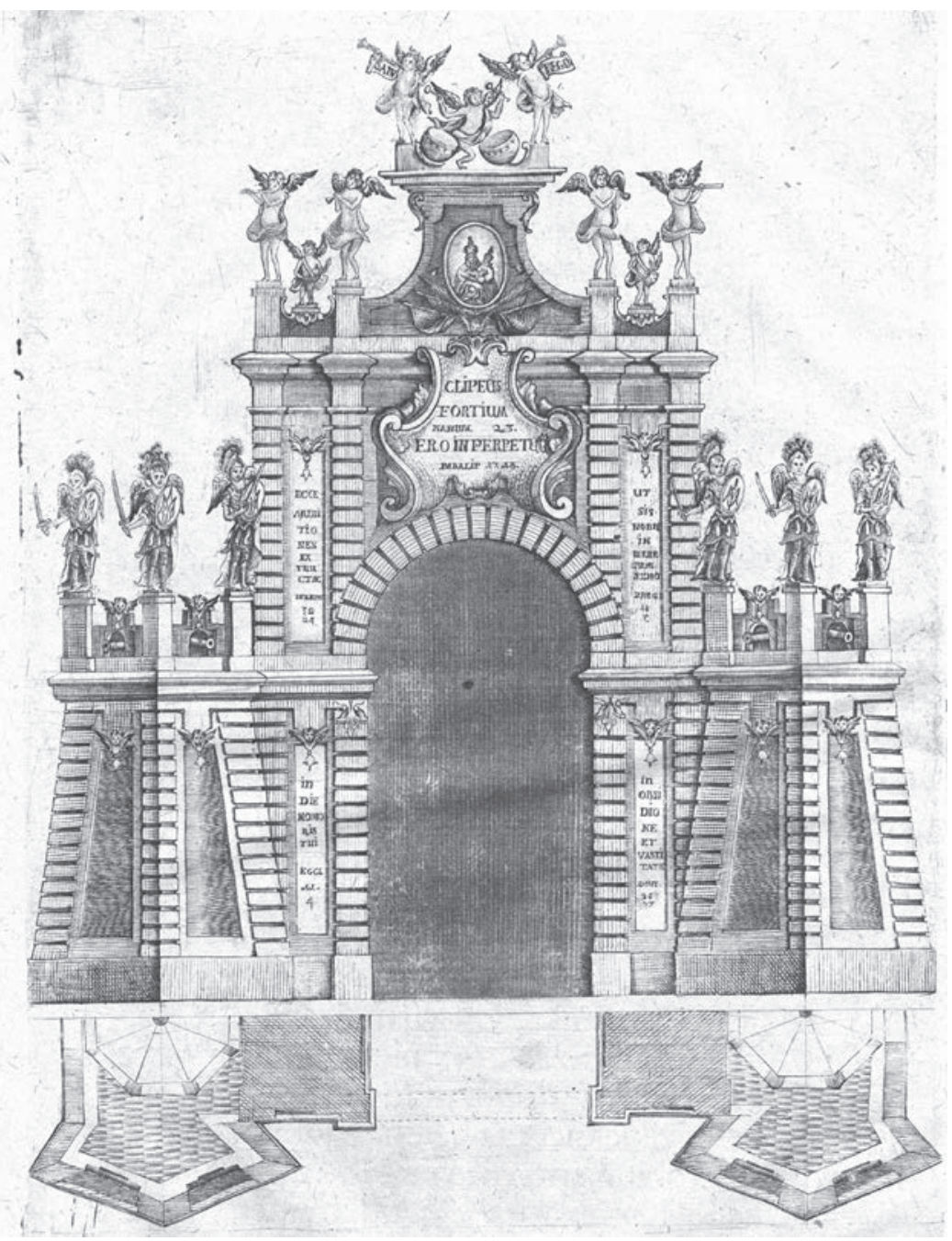

Fig. 1. The seventh triumphal gate built for the coronation ceremony of the miraculous painting of Holy Mary of Berdyczów Ozdoba i obrona ukraińskich krajów . . watykańskimi koronami . . ukoronowana ..., part 1, Berdyczów 1767, f. Www ${ }_{2}$. Jagiellonian Library 58895 Mag. St. Dr. 


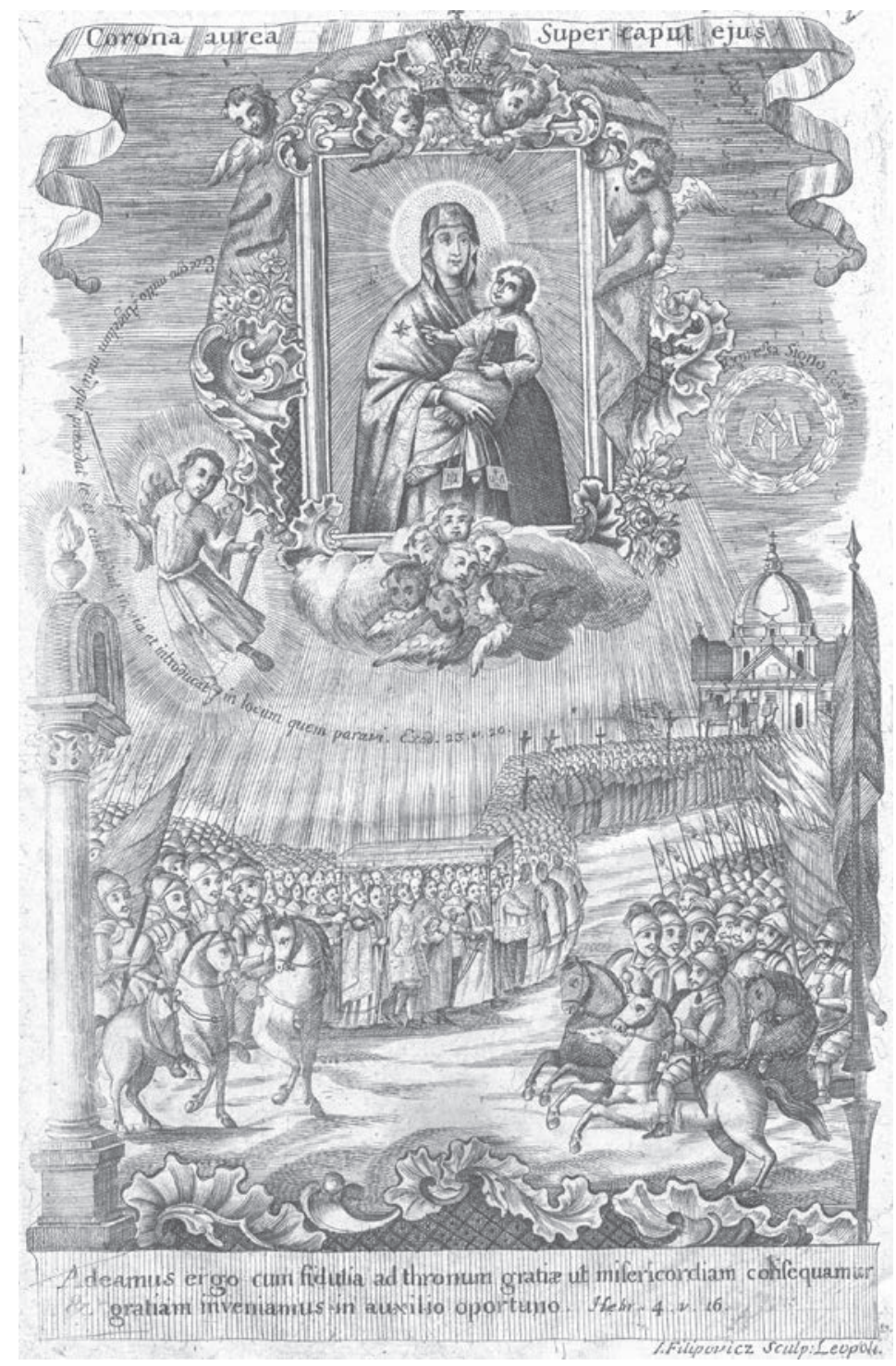

Fig. 2. A march with military assistance in the foreground heading for the crowned image of Holy Mary of Berdyczów, Ozdoba i obrona ukrainskich krajów . . watykańskimi koronami ... ukoronowana ..., part 2, Berdyczów 1767, f. tit. v. Jagiellonian Library 58895 Mag. St. Dr. 
the representative military assistance at the coronation celebrations in Berdyczów, which guards the miraculous painting.

This picture is the imago, if one assumes that the title page is an extensive lemma and the content of the prayer books is an appropriately modified, elaborate subscriptio. It is formally distant from the model epigram as found in the collections of Andreas Alciatus and his followers, but in fact it serves to deepen the sense, remaining the "soul" of the symbolic "body", ${ }^{21}$ that is the representation of the retinues that accompany the miraculous icon in the Berdyczów monastery.

The parallels between the historically authenticated coronation ceremonies, which act as the imago in Kasperowicz's prayer books, and the emblematic treatise Pancarpium Marianum [Garden of Mary] by Joannes David with prints by Théodor Galle from 1607, cited by Lenart, are obvious. ${ }^{22}$ The latter-as the author of Miles pius et iustus stresses ${ }^{23}$-strongly influenced the imagination of the entire epoch and inspired many authors, including Radziwiłł, mentioned above. Kasperowicz's prayer books are the legacy of this trend, and one can even assume that they refer to Pancarpium through the content of the headlines-most clearly in the title of Ogród ...pod straża Królowy Panieńskiej [Garden ... Protected by the Virgin Queen]. In David's work, the engravings together with comments in the following chapters, also present Mary as, among other things (Chap. 23) Civitas refugii [Escape city, cf.: urbes fugitivorum-Joshua 20:2], (Chap. 24) Urbs fortitudinis [The city of valiance-Isa. 2:1], (Chap. 25) Clypeus

strongly influenced European militaristic thought from the Middle Ages to the nineteenth century, writes about the subject of the soldier's vow. See Publius Flavius Vegetius Renatus, Zarys wojskowości [Book II], transl. A. M. Komornicka, Meander 28 (1973), no. 11-12, pp. 488-489. See also Lenart, Miles pius et iustus, pp. 170-179, 206-213 et seq. on the role of holy intercessors and magic in the army.

${ }^{21}$ According to Pontano's categorization, see J. Głażewski, "Libellum composui epigrammaton. Dworzanki Jana Gawińskiego wobec tradycji Emblematów Alciatusa”, Barok 10 (2003), no. 2, pp. 55-56.

${ }^{22}$ I used a copy bound together with another work by David: Paradisus sponsi et sponse, Antwerp 1618. Jagiellonian Library Teol. 1229 b. Mag. St. Dr., Dig. St. Dr. 0004.

${ }^{23}$ Lenart, Miles pius et iustus, pp. 226-228 et seq. 


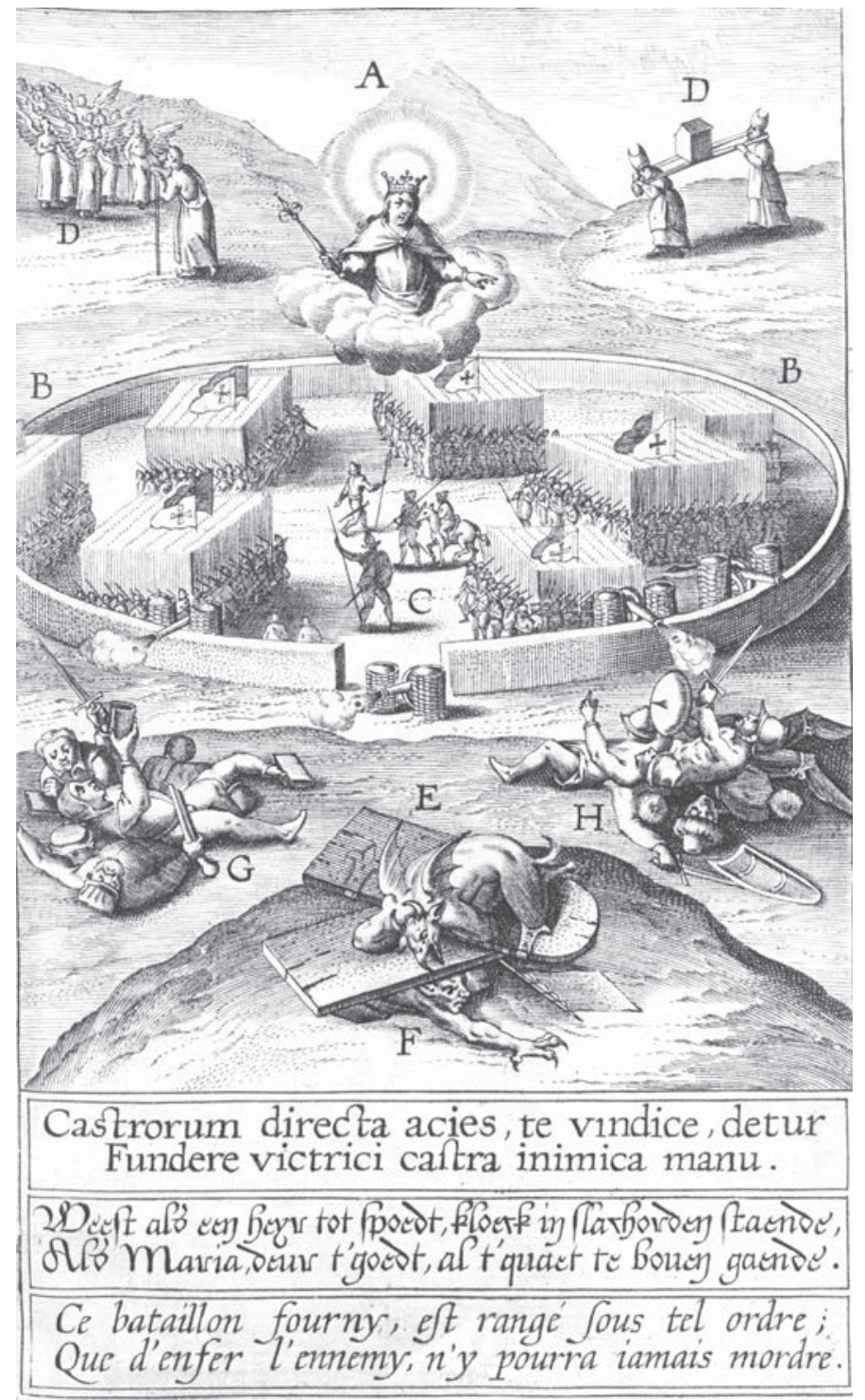

Fig. 3. Mary as "an armoured castle" by J. David, Pancarpium Marianum, Antwerp 1618, fig. 28. Jagiellonian Library Teol. 1229 b. Mag. St. Dr. 


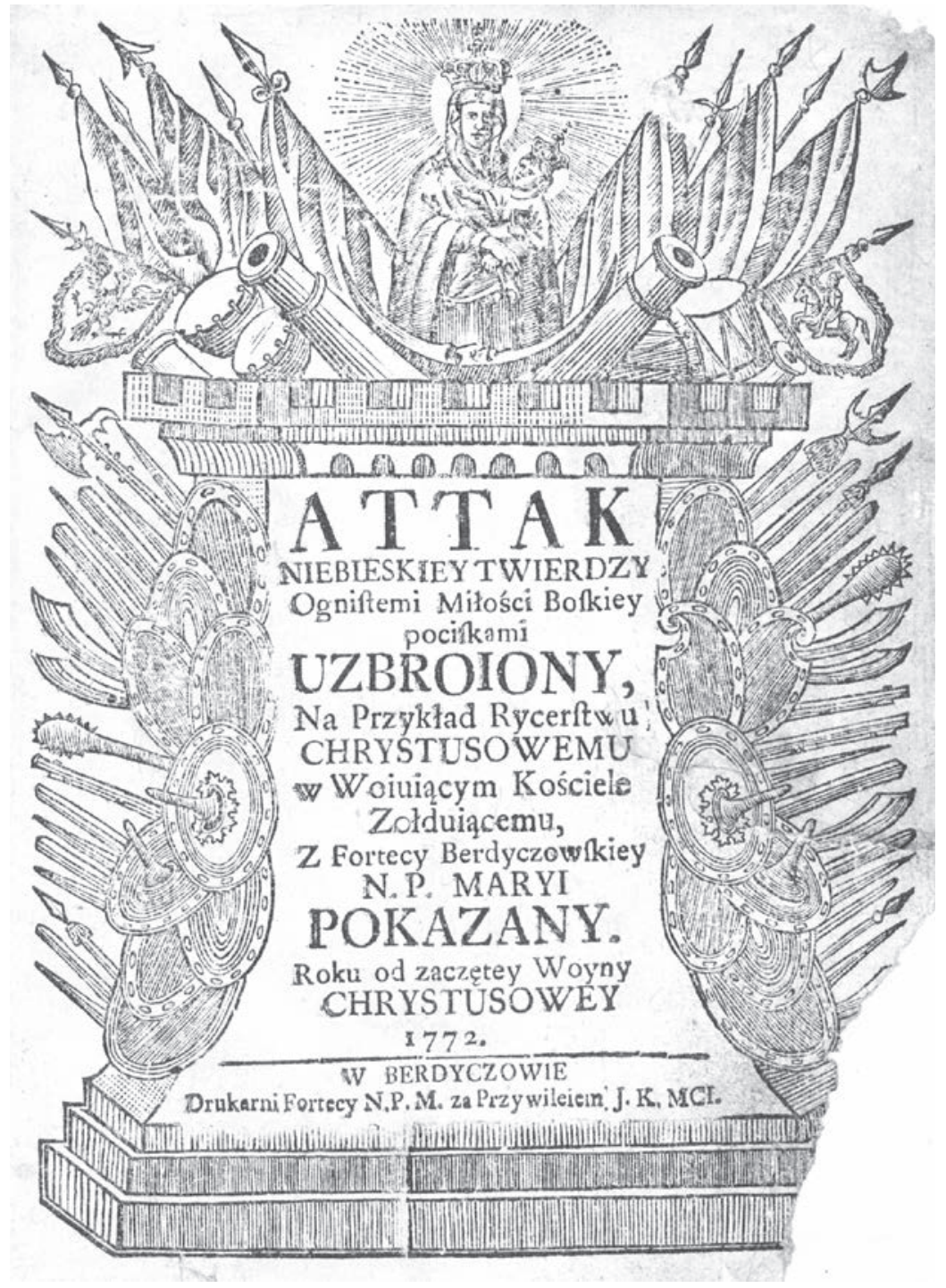

Fig. 4. The title page of the anonymous Atak niebieskiej twierdzy, Berdyczów 1772. Jagiellonian Library 38109 I Mag. St. Dr. 
omnibus in Te sperantibus [A shield for all those who hope in You, cf.: clypeus est sperantibus in se-Prv. 30:5] and (Chap. 28) Castrorum acies ordinata [Armoured castle-Song 6:3 $]^{24}$ (fig. 3).

\section{Atak niebieskiej twierdzy... Miles Christi and Kupido (Amor Divinus)}

Another example is an anonymous work published at the same time as Kasperowicz's prints, written perhaps in the Carmelite community, a book with a military headline and an impressive engraving (fig. 4) on the first page: Atak niebieskiej twierdzy ognistymi Miłości Boskiej pociskami uzbrojony, na przykład rycerstwu Chrystusowemu w wojujacym Kościele żołdujacemu zfortecy berdyczowskiej N. P. Maryi pokazany. Roku od zaczętej wojny Chrystusowej 1772 [The attack of the fortress of heaven with fiery bullets of the divine love shown from the Berdyczów Fortress as an example for the knights of Christ in the militant church. In the 1772th year since the Christ's war began] (Berdyczów). ${ }^{25}$ This prayer book contains, among other things, a list of movable holidays, a calendar with names of patrons, aspirations (of love, regret, humility, etc.), Słodkie gorzkiej męki Jezusa Pana rozmyślanie. Pobudka do rozmyślania Męki Pańskiej [Sweet contemplation on the bitter passion of Christ. A stimulus encouraging the contemplation of the Passion], ${ }^{26}$ hours, litanies, novenas, the Way of the Cross Office, complete Examination of conscience, chaplets, prayers preparing for the Eucharist and thanksgiving prayers, prayers for the

24 They are discussed by Lenart-ibid., pp. 226-227.

${ }_{25}$ Atak niebieskiej twierdzy, Berdyczów 1772. I used a copy from the Jagiellonian Library, shelf mark 38109 I Mag. St. Dr. Work is erroneously paginated: the numbering of pages is continuous to page 568 (I distinguish this part as "a"), the next page (in the middle of the chapter) is marked as 269 , the next pages are numbered after it (part "b").

${ }^{26}$ Commonly known as Snopek mirry z Ogrodu Getsemańskiego [A Bundle of Myrrh from Gethsemane] or Gorzkie żale [Bitter Lamentations]. 
time of pestilence, hunger, war, oppression, danger, pregnancy, and childbirth; supplications for the good upbringing of children, love and harmony in marriage, vocation; prayers for children for their parents, prayers for widows, for the dead; passions and reading on Corpus Christi according to the evangelists. There is also a part entitled Postrzały duszne Miłości Bożej, wybrane z Ludwika Blozjusza [The arrows of God's love aim at the soul, selected from Louis de Blois].

Even with this diversity, we can see the order introduced in the prayer book by dividing it into four parts: (I) "daily prayers" (p. 1a), (II) weekly prayers (p. 61a), and (III) monthly prayers (p. 474a). Part IV contains prayers "for every day of the year. Special prayers to the saint, whose memory the Holy Church celebrates on that day" (p. 519a). However, this arrangement is not sufficient to speak of analogies to secular or "clerical" military structures, and it seems that there is no correspondence between the engraving in the title page, which could precede the allegorical poem, and the content of the volume. The excerpts on the verso side of the first leaf, however, demand an interpretation that makes the title military metaphor understandable and constitutes the keystone of the work's composition. Four pericopes form a sentence here. If one assumes that the image of an armed bastion with a headline is a functional imago and a lemma, the four-line cento will constitute a subscriptio (the instruction included in it is validated in the further parts of the work):

The kingdom of heaven has been subjected to violence, and violent people have been raiding it. Matt. 11:12.

My mother's sons were angry with me. Song 1:6.

In the spirit of fire. Isa. 4:4.

The weapons we fight with are not the weapons of the world, but are powered by God. 2 Cor. 10:4. ${ }^{27}$

27 Atak niebieskiej twierdzy, p. 2 (unpaginated). All quotations from the Bible in English come from The Holy Bible: New International Version, transl. and published by International Bible Society, verified edition, Nashville and London 2011, available online at https://www.biblegateway.com/ (accessed on 25 Oct. 2019). 
Apart from the calendar part, the breviary, which contains a substantial collection of prayers maintained in the tone of the highest religious exaltation, should serve as a medium for the articulation of religious affections and should help the "sons of the mother" to manifest the "spirit of fire". Their "weapons" are "powered by God", which explains why in the drawing there is an armed "Fortress of Heaven", and not its defenders. The category of "fortress" may refer here to the image of both the "kingdom of heaven" and the fortress, exemplified by the Berdyczów fortress. The spearheads and the blades of the axes and sabres in the engraving are "fiery bullets of the Divine Love"; they are also fired by guns and cannons. Atak niebieskiej twierdzy is to serve as an example for "the knights of Christ in the militant Church", which should respond with a similar volley. The battle is therefore fought by the "Fortress of Heavens" (understood in two ways) and the sons of the Church. The emblem thus interprets the meaning of the term "violent people who raid the kingdom of heaven". Traditional enemies of mortals-flesh, world and Satan-are little exposed here. "Violent people who raid the kingdom of heaven" in a "spirit of fire" are "knights of Christ" (implicitly: those who are stationed in the Berdyczów fortress, as well as all others). In one of the services included in the prayer book, the aspiration of a "pious heart" to "Divine Love" was called an "assault". ${ }^{28}$ A detailed picture of this battle can be found in the aforementioned fragment by Louis de Blois, a Benedictine monk whose works were eagerly published in the times of the Polish-Lithuanian Commonwealth and later. In the Postrzaly duszne for the whole week, let us take a closer look at the passages intended for Monday and Tuesday:

Oh most secret and closest Spouse of holy souls, Lord Jesus Christ! I ask you to set my cold heart ablaze with your fiery love, so that I may love you without measure from the deepest secretiveness of my soul. Visit my heart, the only comfort of the sad ones ... ! ${ }^{29}$

28 Ibid., p. 332b.

${ }^{29}$ Atak niebieskiej twierdzy, p. 276 b. 
Finally, dear Jesus, terrify and penetrate my heart with the arrow of your love, so that I may fall salutarily ill in you and swoon because of great longing for you, so that all pleasures will be detestable to me and so that I will only love you, my Lord. ${ }^{30}$

The role of the recipient is to identify with the Bride who turns to the Bridegroom, or Christ; her desire for co-suffering is at the same time a desire for a mystical love union. Both in the cited passage and in the work as a whole, the exchange of "fiery bullets" of love finds conceptual support in the popular imagery, which was prompted, among other things, by evangelical quotations. In Cesare Ripa's Iconology (the first edition with engravings was published in Rome in 1603), one of the most popular emblematic compendiums of his time, three images retain a particularly clear link with the words of Jesus: Ignem veni mittere in terram et quid volo si accendatur [I have come to bring fire on the earth, and how I wish it were already kindled! (Luke 12:49)]. The first one, Miłość bliźniego [Love to Neighbour], is a woman with her head in flames (the above quotation is paraphrased in the subscriptio). ${ }^{31}$ The second, similar, is called the Zbożny afekt [Divine Affection]; it is accompanied by a commentary: The fire burning on ... the head means that our spirit begins to burn with the love of God when it is practiced in a godly affection. ${ }^{32}$ The third one, entitled Pragnienie złączenia się z Bogiem [The Desire to Join with God], is explained as follows: "A flame is gushing from the boy's breast, the same flame that our Lord Jesus Christ brought to earth". ${ }^{33}$

Above all, however, one should pay attention to the motif of the heart pierced with an arrow, the variant of which appears for example in the vision of St Theresa of Jesus, ${ }^{34}$ almost a contemporary of Blois.

${ }^{30}$ Ibid., p. 280 b.

31 C. Ripa, Ikonologia, transl. I. Kania, ed. P. Buscaroli, Cracow 2002, pp. 95-96.

${ }^{32}$ Ibid., pp. 425-426.

33 Ibid., p. 145.

34 "... I saw an angel standing next to me on the left, in a carnal form .... He was not tall, rather small, but very beautiful .... In the hand of this angel, I saw a long 
This motif occupies an important place on the map of the mystical imagination of the epoch, ${ }^{35}$ and in the case of our prayer book it is one of the keys to the allegoresis of the emblematic concept of the work, in which passionate feelings are divided into subsequent acts, "affections", motives; In the aforementioned Dyskurs nabożny [Devotional Discourse], Radziwiłł calls similar prayers bullets "from a spiritual rifle":

Souls shoot prayers and aspirations from their honest hearts at God ...; ascribing this not to themselves, but to Him, they fall to the earth, humbly accepting that earth is dust; then they load their spiritual rifle again and even stronger than before shoot their prayers at the invading adversaries, with affection and with the fire of love. ${ }^{36}$

The seventeenth-century prints include numerous emblematic representations of the Cupid theme. ${ }^{37}$ As a result of a turn towards

golden spear, and its iron head at the very end was as if made of fire. With this spear, I thought, he pierced my heart a few times, penetrating it all the way into my bowels. Every time he pulled out the spear, I felt as if he was pulling out my bowels with it; so he left me with all the burning zeal of God's love", św. Teresa od Jezusa, Księga życia, transl. H. P. Kossowski, Cracow 1997, pp. 385-386.

${ }^{35}$ It also includes the image of the wounded heart of Christ, whose cult began in the seventeenth century and developed in the eighteenth century. In Poland, Kasper Drużbicki SJ (1587-1662) significantly contributed to this. According to Estr. (XV, 335) his work Meta cordium cor Jesu et SS. Trinitatis was published five times in less than fifteen years (Kalisz 1683, Poznań 1683, Kalisz 1691 and 1693), together with the edition Serce Jezusowe meta albo cel serc stworzonych od ks. Kaspra Drużbickiego Societatis Jesu pospolitej wszytkich mitości (Poznań 1687; Estr. also noted three later editions from Lviv [1730, 1878, 1885] and an English translation [1890]).

${ }^{36}$ Radziwiłł, Dyskurs nabożny, p. 291.

${ }^{37}$ J. Pelc, Stowo i obraz na pograniczu literatury i sztuk plastycznych, Cracow 2002, pp. 191-192. The likenesses of Cupid with his typical attributes (bow and arrows) are accompanied by other emblematic images referring to them, which include motifs of fire/ignis (flames/flammae, heat/calor, lightning/fulmen), wounds/ vulnera, suffering that accompanies pleasure-see Emblematy mitosne (emblemata amatoria) Jakoba Catsa W trzech różnych językach. A także w ujęciu polskim z XVII wieku przedstawione, ed. J. Pelc and P. Pelc, Warsaw 1999, pp. 24-25, 30-33, 46-47, 66-67, 70-71, 90-91 et seq. 
"holy eroticism", as Janusz Pelc writes, ${ }^{38}$ the figure of Amor Profanus is replaced by Amor Divinus, who appears, among others, in several collections of Antwerp emblems frequently imitated throughout Europe. The next edition of the "synthesis of religious accomplishments of Netherlandish emblematics", ${ }^{39}$ that is a compilation collection entitled Les Emblèmes d'Amour Divin et Humain ensemble (the first edition was published in Paris in 1631 and was prepared by the Capuchin Louis of Louvain) inspired, among others, Zbigniew Morsztyn in his work on his Emblematy [Emblems], which were part of the Muza domowa $[\text { Domestic Muse }]^{40}$-a work chronologically later than the Antwerp edition (Amoris Divini et Humani effectus varii published in $1626^{41}$ ) with handwritten epigrams of Morsztyn. His Emblems-a certain sum of the religious imagination of the epoch in which the tradition of mystical mating was eagerly used ${ }^{42}$-are one of the most important reading contexts for the Atak niebieskiej twierdzy. Later engravings in Morsztyn feature, for example, the Bridegroom showing the heart wounded by the arrow of the Bride (Emb. 13) and the Bride hit in the heart by an arrow of the Bridegroom (Emb. 19); both of them crossing side arms in fencing exercises (Emb. 36) and presented with arches aimed at each other (Emb. 59); also the Bride, from whose heart arrows pointed upwards come out (Emb. 101). ${ }^{43}$ The Paris edition of Les Emblèmes is also decorated with a bordure, later included in Paulina and Janusz Pelc's edition of Morsztyn's Emblems. ${ }^{44}$ Its sides show crossed pennants with attached sabres, drums and, what is interesting for us, rifles. In the lower part of the frame there is a bowl

38 Pelc, Słowo i obraz, pp. 192-195.

39 Ibid., p. 195.

40 Ibid.

${ }^{41}$ See Miłości Boskiej i ludzkiej skutki różne. Wraz z siedemnastowieczną wersja tekstów do „Amoris Divini et Humani effectus varii”, ed. P. Pelc and J. Pelc, Warsaw 2000 .

${ }^{42}$ See P. Pelc and J. Pelc, "Wstęp", in Z. Morsztyn, Emblemata, ed. J. Pelc and P. Pelc, Warsaw 2001, p. X.

${ }^{43}$ Ibid., pp. 30, 42, 76, 122, 208.

44 See Pelc and Pelc, "Wstęp", p. XIX. 
with a heart pierced by an arrow (Emb. 91 also depicts a man bringing a similar bowl with a heart before the divine throne ${ }^{45}$ ), while at the top there is a fiery heart with two crossed arrows.

Jan Pelc agrees with the comments of researchers who point to the analogy between Morsztyn's Emblem 19 and Bernini's sculpture of St Teresa's Ecstasy in the church of Santa Maria della Vittoria in Rome. ${ }^{46}$ As regards the Atak niebieskiej twierdzy and earlier representations of God's Love inspired by the Biblical-Augustinian current, including those that resulted from the transformation of Cupid, there is still a need to consider the possible impact of not only the early (from the turn of the fifteenth and sixteenth centuries) iconographic and textual representations of the mystical conjunction of the Bridegroom and the Bride, ${ }^{47}$ but also of the works of Carmelite mystics, including St Teresa of Ávila, whose great popularity in the seventeenth century was the result of her beatification (1614) and canonisation (1622) process. ${ }^{48}$ The Atak niebieskiej twierdzy thus remains firmly rooted in a long tradition centred around battle-love motifs. Through its military references it also refers to a different, extremely strong current of religious and warlike imagery. However, the battle with the amorous, human-heavenly fiery shots fired against the "fortress" or from the "fortress" appears as an innovation against the background of allegorical wars that involved personified virtues and vices, heroes armed with their own qualities and the attributes of their clerical life,

45 Morsztyn, Emblemata, p. 188.

46 Pelc, Stowo i obraz, p. 272.

${ }^{47}$ Ibid., p. 192. Interest in the figurativeness of the Songs of Songs appeared much earlier. We find it both in the earliest commentators of the Bible (for example, Orygenes, Komentarz do „Pieśni nad pieśniami”. Homilie o „Pieśni nad pieśniami”, transl. and ed. S. Kalinkowski, Cracow 2005) as well as the outstanding mediaeval mystics (see, among others, św. Bernard z Clairvaux, "Kazania do Pieśni nad Pieśniami”, transl. R. Tichy, in Wszystko to ze zdziwienia. Antologia tekstów filozoficznych z XII wieku, selection and ed. M. Frankowska-Terlecka, Warsaw 2006.

${ }^{48}$ See. B.J. Wanat OCD, "Bibliografia świętej Teresy od Jezusa w Polsce”, in Otrzymałam ducha mądrości. Księga pamiątkowa z okazji ogłoszenia świętej Teresy od Jezusa Doktorem Kościoła Powszechnego, ed. O. Filek, Cracow 1972, p. 380 et seq. 
representations of devilish, worldly and carnal storm on the fortress which represents the soul, as well as analogous field manoeuvres, as in e.g. St Paul (2 Cor.), St Augustine (De agone christiano, c. 396), Prudentius (Psychomachia, written in the late fourth century or at the turn of the fourth and fifth centuries), St Bernard of Clairvaux (Liber ad milites Templi de laude novae militiae, between 1128 and 1136), Erasmus of Rotterdam (Enchiridion militis christiani, 1503), Lorenzo Scupola (Combattimento spirituale, 1589). Polish works include poems by Bernard Kołek (Wizerunek duchownego żołnierza, 1619), Wacław Potocki (Rozbój duchowny, ca. 1616), Stanisław Kołakowski (Wieża Dawidowa ze wszelka armatura, between 1620 and 1621), Szymon Okolski (Żołnierz duchowny, 1649), Elżbieta Drużbacka (Forteca od Boga wystawiona, 1752), as well as numerous other prints that refer to the tradition of milites Christi. ${ }^{49}$

\section{Wojsko serdecznych afektów by Hieronim Falęcki (1677-1756)}

The next prayer book ${ }^{50}$ to which we will devote our attention was written three decades earlier than the works already discussed. It is also possible that, having quickly gained a great, though short-term popularity, ${ }^{51}$ it was an additional inspiration for them. Falęcki referred both to a specific image of the army arranged into an array, proving at least a superficial orientation in the subject of the battle strategy, and

${ }^{49}$ Due to the breadth of the bibliography itself, I would like to recommend the above mentioned studies, especially by Lenart and the earlier ones by Sokołowski, Malicki, and Herman.

${ }^{50}$ It is also a collection of retreat exercises.

${ }^{51}$ On this subject see Litwornia, "Samsonowy oręż", pp. 451-452; more in the paper: I. Słomak, "Wojsko serdecznych afektów Hieronima Falęckiego - z problematyki edycji, poetyki i recepcji, in Sarmackie theatrum V. Między księgami, ed. M. Barłowska and M. Walińska, Katowice 2012. 
to a specific imaginarium of the mystical tradition, within which the domain of Cupid was a domain of combat. Thus, he combined two related concepts (a prayer book referring to the formula of the ideal of the Lord's army and a book as a collection of "affections" serving the victorious "storming" of the heavens as well as the hearts of readers), whose relationship in Kasperowicz and the Atak niebieskiej twierdzy was less evident in favour of greater clarity of each of them.

The author, a Discalced Carmelite, published his work under the monastic name of Father Hilarion of the Blessed Sacrament. It appeared in several editions (printed three times in Poczajów with the date of 1739 and again in Poznań in $1746^{52}$ ) with the headline Wojsko serdecznych nowo rekrutowanych na większa chwałe Boska afektów [The Army of Heartfelt Affections Newly Recruited to the Greater Glory of God]. ${ }^{53}$ Since a detailed discussion of the issues that interest us in the whole work would exceed the planned size of this study,

52 Litwornia, "Samsonowy oręż", pp. 449-450 et seq. discusses the issue of editions of Wojsko serdecznych . . a afektów more broadly in: Słomak, "Wojsko serdecznych afektów”.

${ }^{53}$ H. Falęcki, Wojsko serdecznych ... afektów, Poznań 1746. All quotes are from this edition, Jagiellonian Library 391218 II Mag. St. Dr. About Falęcki’s biography see: I. Słomak, "Ciało a (nie tylko ignacjańskie) ćwiczenia duchowne. Święty Jan od Krzyża - święty Ignacy Loyola - ojciec Hilarion od Najświętszego Sakramentu”, Anthropos 10-11 (2008). A bibliography of earlier works whose authors devoted more attention to Falęcki (A. Czyż, Ja i Bóg. Poezja metafizyczna późnego baroku, Wrocław 1988; Litwornia, "Samsonowy oręż”; A. Nawarecki, Czarny karnawał. „Uwagi śmierci niechybnej" księdza Baki - poetyka tekstu i paradoksy recepcji, Wrocław 1991; A. Nowicka-Jeżowa, Pieśni czasu śmierci. Studium z historii duchowości XVI-XVIII wieku, Lublin 1992; M. Prejs, Poezja późnego baroku. Główne kierunki przemian, Warsaw 1989), should be today supplemented by the doctoral thesis of Maciej Pieczyński (on the works of Józef Baka, Karol Mikołaj Juniewicz and Falęcki), currently written at the University of Warsaw, and his paper ("Pomiędzy błazeństwem a capriccio. Uwagi o grotesce w późnobarokowej poezji religijnej”, Barok 12 (2005), no. 2, pp. 95-113). The author is currently preparing a dissertation on the poetics and rhetoric of Wojsko serdecznych afektów, part of which is this paper. The allegorical and visual dimension of Falęcki's work is mentioned only by Czyż, Ja i Bóg, pp. 66-69. 
apart from a brief outline of the general concept, we will only deal with its title page and a selected fragment.

\section{(a) Heading}

The title page features information about the commanders of the five military units presented below; they are under the command of Michal Serwacy Korybut Wiśniowiecki and follow "Jesus stretched out on the cross". The headline consequently seems to be an introduction to the work in which the spiritual battle, as a certain aspect of literally understood war, will be subordinated to the ideology of the Christian bulwark. In fact, the exposition of the name of the great benefactor of the monastery in Wiśniowiec, with which Falęcki was connected for the longest time, is a gesture of thanksgiving and should be separated from the proposed concept of piety. However, this gesture, while being obvious, does not look ostentatious; Michał's name appears in a double function, which results from the emblematic character of the title page. Like the headings of the individual chapters, the long title of the work serves as a lemma for an allegorical picture that can be reconstructed on its basis. In this case, we must refer to sources informing about the furnishings and decoration of the now non-existent church in Wiśniowiec. As the monastery chronicles inform us, ${ }^{54}$ there was a main altar there dedicated to Michael the Archangel with the image of the patron saint of the monastery ${ }^{55}$ Next to him, on the side wall of the chancel, there was a portrait of the founder, Michał Serwacy Wiśniowiecki, the supposed author of two four-line poems placed on the wall under the choir:

Michał Hieremi founded this church, Michał, the King of Poland, provided the funds for it, Michał the Chancellor finished it brilliantly,

Saint Michael, protect it at all times.

He presents this symbol of gratitude and good will to you

${ }^{54}$ Wanat, Zakon Karmelitów Bosych w Polsce, p. 482.
55 Ibid., p. 482. 
Oh, my God, because you saved it from wars and captivity

With the hand of Saint Michael,

And saved his life, honour and fortune. ${ }^{56}$

The name Michał, in which "the God preserves honour, fame, and common welfare of the whole Homeland", displayed centrally (in one of the three editions of Poczajów and in the Poznan edition also with a larger font ${ }^{57}$ ), in a different way than the name and titles, among which there is also the dignity of the hetman (fig. 5), may refer ${ }^{58}$ in Falęcki's work both the prince and the angelic hetman, Archangel Michael, the patron saint of the Wiśniowiecki family, who repeatedly fought for the "common welfare, honour and fame" of the Commonwealth due to the turbulent times in which they lived. Michał Serwacy and Michael the Archangel have the common byname of defender, that is the knight of Christ, derived by Falęcki from the second name of the Carmelite donor and emphasised by paronomasia (the etymon of words "Serwacy" and "preserves", Polish konserwuje, means "to watch", "to guard", "to save"). Saint Michael the Archangel, in turn, remained one of the prototypes of God's warriors as, among others (Revelation 12:7-9), the commander of Christ's armies fighting against the Leviathan. He was the hero whom preachers and authors of books written according to

${ }^{56}$ As cited in: ibid., p. 482. The poem speaks of Jeremy Michał Korybut Wiśniowiecki, a Ruthenian voivode famous especially during the Polish-Cossack wars of the mid-seventeenth century; the Carmelite monastery and church in Wiśniowiec was founded by him in 1644. The church buildings destroyed during the Cossack invasion (1655) were renovated by Michał Korybut Wiśniowiecki, King of Poland. The monastery and the church were then completely destroyed by the Turkish army (1675), which also put to the sword all the inhabitants of Wiśniowiec, including the monks. After the death of the King, Wiśniowiec passed into the hands of the older line of the family; it was inherited by Konstanty Krzysztof, son of Janusz Wiśniowiecki, who died prematurely. The foundation was rebuilt only by Krzysztof's son, MichałSerwacy Korybut, who secured the funds for this purpose with an act from 1718 and maintained the monastery in the following years. See ibid., pp. 207-208.

${ }^{57}$ Learn more about the differences between editions: Słomak "Wojsko serdecznych afektów".

${ }^{58}$ I owe this observation to the remarks of dr hab. Maria Barłowska. 
the recommendations of Antonio Possevino (the creator of Bibliotheca selecta ... attached to some editions of his Il Soldato Christiano con l'instruttione de' capi dell'essercito catolico - written in 1569, a popular textbook on writing pious books for armies ${ }^{59}$ ) willingly set an example for soldiers in the sixteenth, seventeenth, and eighteenth centuries. The name of the patron saint of the Polish Military Brotherhood of St Michael the Archangel, founded at the end of the sixteenth century by the Bernardine Marcin of Bydgoszcz (his ideals were still popular in the mid-eighteenth century ${ }^{60}$ ), was also used as a battle cry. ${ }^{61} \mathrm{~A}$ hypothetical imago, referred to in Falęcki's lemma, which paraphrases the last verse of Michał Serwace's "symbol" (in fact, the direction of inspiration remains unobvious-the church was consecrated in 1740 , the year of the first edition of Wojsko serdecznych . . afektó $w^{62}$ ), so there could be two images of Christ's hetmans in its centre, who prove the "heartfelt and affectionate" army of Father Hilarion.

\section{(b) Short description}

In order to provide Mary's allegory as an organised army with a conceptual support, Radziwiłł outlined a plan according to which in his time it was customary to arrange troops for a battle; he also emphasised the persuasive effectiveness of the army standing in formation, "graceful to its fellows" and "frightening" those standing in front of it, ${ }^{63}$ unlike the troops stationed in a camp. The model formation is as follows:

The hetman himself set the army in array; the colonels, calvary captains, cavaliers and infantry are all under his command; he shall put the rear-guard

${ }^{59}$ Lenart, Miles pius et iustus, pp. 28, 32-34, 54-65, 193-194 et seq.

${ }^{60}$ Translations of the popular canonical hours to St Michael are also published in Kasperowicz's prayer book (Obóz uszykowany wojsk niebieskich, Berdyczów 1769, p. 1 et seq.) and the Atak niebieskiej twierdzy (p. 141a et seq.).

${ }^{61}$ See Lenart, Miles pius et iustus, pp. 48-54, 170, 190, 217-223, 256 et seq. Further bibliography therein.

62 Wanat, Zakon Karmelitów Bosych w Polsce, p. 481.

${ }^{63}$ Radziwiłł, Dyskurs nabożny, p. 273. 


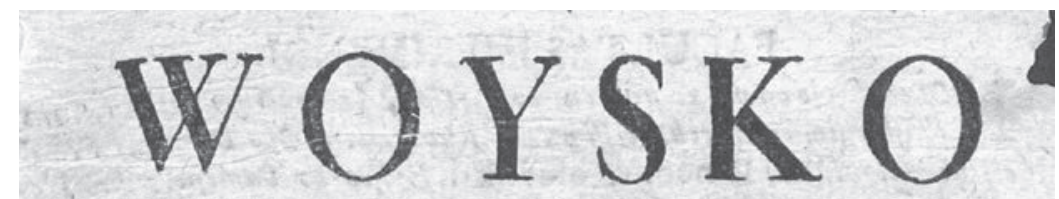

SERDECZNYCH NOWO-REKRUTOWANYCH

Ná więkizą Chwałę Bolką áffektow,

\section{Pod Kommenda.}

IASNIE OSWIECONEGO XIAZECIA

De Primis Principibus, bo

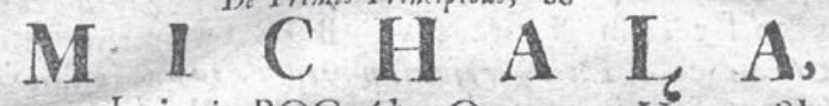

w ktorego Imieniu BOG cáłey Oyczy zny Honor, Sławę, y cáłość konferwuie; ile

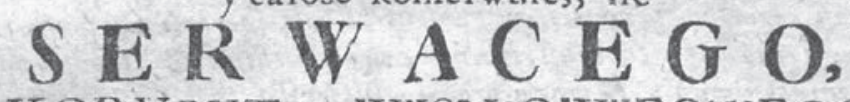

KORYBUTA WISNIOWIECKIEGO,

Woiewody Wileńlkiego, WielkiegoX.L. W.HETMANA,

ále iefzcze więkfzego przed BOGIEM, Niebem, y cáłynı

Pollkim Swiátem, wyfokich zaflug, Prerogátyw wodzá,

ciągnieniem záwyćiagnionym náKrzyzu Jezusem, trzemá Kolumnámi, Wiáry, Nádźiei, Miłości,

\section{D A C E,}

Roku, kiedy Syn Bofki Regimentarz cátego Swiátá, zdamßy komende náturze ludzkiey ná moynie trzydżieflu. trzech lat bymßy BOGIE M, ftat fię Cztoniekiem, wielkq uczynit odwage. áby nam wiecznq zámoiomat chioatę; $174^{\circ}$. powtornie drukiem Roku 1746 .

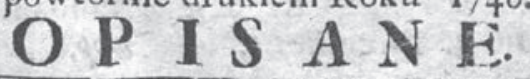

w POZNANIU, w Drukárni Akádemickiey Kofztem Woyćiechá Wolnfkiego Introligatorá.

\section{weman, wis. wes 108}

Fig. 5. The title page of Wojsko serdecznych afektów by H. Falęcki, Poznań 1746. Jagiellonian Library 391218 II Mag. St. Dr. 
on and oftentimes also the third guard. The brave and experienced leader arranges his army on flat and spacious field so that the army appears more impressive. At the forefront, there will be the good and experienced soldiers, the majority of the army in the middle, the wings on left and right, and at the rear, for reinforcements and so that the enemy will not attack from behind, a group of non-warriors or an imbellium turba and the camp equipment before them, and finally the rear guard ... The army shall be equipped with trumpets and drums; there is a battle cry, which is a secret in the foreign countries, so that few people in the enemy's army know it, but in Poland the battle cry is explicitly announced.

The units of Wojsko serdecznych . . . afektów were also clearly arranged into a combat formation; ${ }^{64}$ just after the title page, approvals and description of the battle cry there was a short description ${ }^{65}$ within which the position relative to each other and organisation of the forces of adversaries were conceptualised. In the field, there are: Death "in vanguard", Delight "holding the main body", "Hell in the rearguard", and the Body in "side guard". They are attacking the Man who is being helped by Falęcki's army. The short description includes-apart from abstracts of individual parts (functional divisions) - also four passages called combat intelligence.

Their purpose has been defined as: (1) "expelling" the "bragging" knights; (2) "dismissing young warriors who serve both Bellona and Cypris"; (3) "reprimanding all fugitives"; "conducting reconnaissance to find out that there is beauty in courage displayed in the eyes of people, but being courageous in God's eyes is even more beautiful".

The subsequent parts of Wojsko serdecznych ... afektów were then presented here:

${ }^{64}$ Its structure is slightly different from Radziwiłł's concept, although it is in line with other rules of contemporary warfare (especially, as we will see, the role of artillery). Some of the innovations are dictated by the complexity of the figure of the army depicted here, especially in the following chapters, which I discuss in more detail in my doctoral dissertation on Falęcki.

${ }^{65}$ No pagination within the short description. At this point in the previous three editions dated 1739 (Poczajów) there is also a panegyric section devoted to Wiśniowiecki. 
I. In Part One, "The front guard is held by the Major General, ... the Incomprehensible Divine Affection", who leads "the fiery regiments which shoot various flames of Divine love at human hearts".

II. In Part Two "The main guard . . . is held by the Sacramental Affection of the true God and man in a circular wafer". Here, "the enthusiastic King of Kings confers decorations on the benevolent hearts of his ministers and asks for them to reciprocate his love".

III. In Part Three, at the "side guard", "Jesus' heart satiates his votaries with crimson, adorns them with this superbly beautiful colour and arouses mercy in them".

IV. "In Part Four, the main square guard . . . is held by a lost Soldier, a sinner on the square of vanity, who full of tears and heartfelt sorrows, having gathered succour, goes to the rescue of the soul conquered by Satan".

V. In Part Five, "Pious Melancholies accompanied by the select cavalry of salutary persuasions command rear guard". Falęcki speaks of "melancholies" as "armaments" with which subsequent "Volunteers" are equipped "to conduct reconnaissance". The author compares this chapter to a mirror in which one must "look" in order to experience transformation.

We should notice here the ingenious realisation of the concept contained in the title: thanks to the formal shape of the work modelled on an arranged military array, we obtain the effect of a vivid spatial image; Wojsko serdecznych... afektów is thus part of the visual literature trend. At the same time, it is subordinated to the emblematic tradition, as we have already signalled when discussing the headline; the title pages of the chapters could be elaborate lemmas, and the chapters themselves could be subscriptios to hypothetical picturae - allegorical representations "at the forefront" of a considerable number of subchapters. 


\section{(c) Chapter or "unit" one}

In part one, these subsections are equivalents of "fiery regiments" subordinated to the "incomprehensible Divine Affection". Another term for their commander, "Major General", refers to a function that actually existed in the Lithuanian army from the middle of the seventeenth century; it was the position of "artillery general", "master of artillery" or "senior of the cannon". In the military hierarchy, he was in charge of the arsenal commanders (Pl. cekhauz from German Zeughaus), while the camp and field armoury commanders (Pl. cejgwart from German Zeugwart) were subordinated to the hetman. In a hierarchy of importance, his position was situated lower than that of the latter, which, however, was not associated with formal subordination. ${ }^{66}$ Falęcki's "General", as we can deduce from the overall concept of the work, is however, in charge of field artillery. On the basis of metonymy, the "regiments" subordinated to him mean "fires" "shot at human hearts" - the subchapters corresponding to the "regiments" are also provided with headlines announcing the expression of feelings. After reading, it turns out that the vector of gunshots is not directed toward human hearts, but toward Christ. However, this is understandable when we assume that these "fires" remain prayers which, following the authors of the Atak niebieskiej twierdzy or the Dyskurs nabożny we can describe as "ejaculations". The semantics of representations that employ the motif of Cupid and transform it (here "arrows" do not mean archery arrows, but-what is a sign of the timesfirearms) assumes, in turn, the bidirectionality of attacks from heaven to the human heart and vice versa. As we can see in the Atak niebieskiej twierdzy, this exchange suffices to repel the "worldly", "bodily" or "devilish" opponent. Falęcki's "Fires" are: 1) Encouragement for Divine Love; 2) Expression; 3) Heartfelt love; 4) Condolence; 5) The whole actions ends in a blink. Every time, every hour for the love of God; 6) Confusion; 7) Thanksgiving; 8) Gratiarum actio; 9) Alia gratiarum actio; 10) Suplication; 11) Enroling ... oneself for eternal submission; 12) Conference

${ }^{66}$ H. Wisner, Rzeczpospolita Wazów, vol. 2: Wojsko Wielkiego Księstwa Litewskiego, dyplomacja, varia, Warsaw 2004, pp. 49-52. 
with Jesus ...; Confirmation of heartfelt affection against Jesus; 14) All are gripped by fear ...; 15) The one who is nominated for salvation, the votary of the sweetest of names, Jesus and Mary. ${ }^{67}$

The "missiles" are released by the "fiery regiments" under the dictation of the "incomprehensible Divine affection", and they also move-by implication-Falęcki's pen. When these "fires" reach the reader during reading, they are to become a carrier of reading affections, this time directed upwards. It seems that verb forms were deliberately adjusted here, so that the reader of Wojsko serdecznych ... afektów could speak individually ... in places designated for this purpose-the male genus is usually followed here by an alternative female form, as in the example: "so that I could fulfil this affection more effectively" [impossible to render in translation, as Polish has both male and female forms of verbs, which English has not-K. S.]. ${ }^{68}$

If, in the end, we attempt to clarify the shape of the allegorical representation or the imago of first part of the prayer book, it would be, roughly speaking, a combination of a painting recorded by Bernini or the authors of emblems copied by Zbigniew Morsztyn, the title page of the Atak niebieskiej twierdzy and the Carmelite coat of arms in the form established at the end of the sixteenth century and preserved in almost unchanged form until today-in its upper part we see a ribbon with the inscription Zelo zelatus sum pro Domino Deo exercituum ("I have been very zealous for the Lord God Almighty"-1 Kings 19:10), and below a hand holding a flaming sword directed diagonally upwards ${ }^{69}$

Translated from Polish by Kaja Szymańska

${ }^{67}$ Falęcki, Wojsko serdecznych ... afektów, pp. 2-49.

${ }^{68}$ Ibid., p. 5. Thus, the author of Wojsko serdecznych ... afektów (sources testify to his activity as a preacher-see Słomak, "Ciało"), as an intermediary of "heartfelt" "missiles", assumes the role that Marcus Tullius Cicero once attributed to effective speakers, that is the role of hetman: "and as a skilful general posts the cavalry, the infantry, and the light troops, where each of them can act to most advantage, so Antonius drew up his arguments in those parts of his discourse, where they were likely to have the best effect", Cicero, Brutus, a History of Famous Orators, transl. E. Jones, London 1776, p. 92.

${ }^{69}$ J. Zieliński OCD, Herb Karmelu. Historia, symbolika, duchowe przesłanie, Cracow 2001, p. 4 et seq. 


\section{Bibliography}

\section{Primary sources}

Atak niebieskiej twierdzy, Berdyczów 1772.

Bernard z Clairvaux, św., "Kazania do Pieśni nad Pieśniami", transl. R. Tichy, in

Wszystko to ze zdziwienia. Antologia tekstów filozoficznych $z$ XII wieku, selection and ed. M. Frankowska-Terlecka, Warsaw 2006.

Biblia sacra vulgatae editionis ... edita Romae ex Typographia Apostolica Vaticana MDXCIII. Edito nova auctoritate summi pontifices Leonis XII excusa, Frankfurt: typis et sumptibus Andreae, 1826.

Cicero, Brutus, a History of Famous Orators, transl. E. Jones, London 1776.

Emblematy miłosne (emblemata amatoria) Jakoba Catsa W trzech różnych językach.

A także w ujęciu polskim $z$ XVII wieku przedstawione, ed. J. Pelc and P. Pelc, Warsaw 1999.

Falęcki, H., Wojsko serdecznych . . afektów, Poznań 1746.

The Holy Bible: New International Version, transl. and published by International

Bible Society, verified edition, Nashville and London 2011, available online at https://www.biblegateway.com/ (accessed on 25 Oct. 2019).

Kasperowicz, A. G., Obóz uszykowany wojsk niebieskich, Berdyczów 1769.

Kitowicz, J., Opis obyczajów za panowania Augusta III, ed. R. Pollak, Wrocław 1970. Miłości Boskiej i ludzkiej skutki różne. Wraz z siedemnastowieczna wersją tekstów do „Amoris Divini et Humani effectus varii”, ed. P. Pelc and J. Pelc, Warsaw 2000. Morsztyn, Z., Emblemata, ed. J. Pelc and P. Pelc, Warsaw 2001.

Orygenes, Komentarz do „Pieśni nad pieśniami”. Homilie o „Pieśni nad pieśniami”, transl. and ed. S. Kalinkowski, Cracow 2005.

Ozdoba i obrona ukraińskich krajów, przecudowna w berdyczowskim obrazie Maryja... ukoronowana..., Berdyczów 1767.

Publius Flavius Vegetius Renatus, Zarys wojskowości [Book II], transl. A. M. Komornicka, Meander 28 (1973), no. 11-12, pp. 488-489.

Radziwiłł, A. S., Dyskurs nabożny. .., Cracow 1650.

Ripa, C., Ikonologia, transl. I. Kania, ed. P. Buscaroli, Cracow 2002.

Teresa od Jezusa, św., Księga życia, transl. H. P. Kossowski, Cracow 1997.

\section{Secondary sources}

Czyż, A., Ja i Bóg. Poezja metafizyczna późnego baroku, Wrocław 1988.

Electronic Database of Estreicher's Bibliography (EBBE), available online at www.estreicher.uj.edu.pl (accessed on 1 Jan. 2011).

Głażewski, J., "Libellum composui epigrammaton. Dworzanki Jana Gawińskiego wobec tradycji Emblematów Alciatusa”, Barok 10 (2003), no. 2. 
Herman, S., Wojna i żotnierz w okresie kontrreformacji (do roku 1648). Szkice z dziejów literatury polskiej i obcej, Zielona Góra 1983.

Kopeć, J., "Godzinki”, in Encyklopedia katolicka, vol. 5, Lublin 1989.

Lenart, M., Miles pius et iustus. Żotnierz chrześcijański katolickiej wiary w kulturze i piśmiennictwie dawnej Rzeczypospolitej (XVI-XVIII wiek), Warsaw 2009.

Litwornia, A., "Samsonowy oręż ojca Gaudentego", in Świt i zmierzch baroku, ed. M. Hanusiewicz, J. Dąbkowska, and A. Karpiński, Lublin 2002.

Malicki, J., "Wacława Potockiego Rozbój duchowny", in J. Malicki, Legat wieku rycerskiego. Studia staropolskie dawne i nowe, Katowice 2006, pp. 209-233.

Nawarecki, A., Czarny karnawat. „Uwagi śmierci niechybnej” księdza Baki-poetyka tekstu i paradoksy recepcji, Wrocław 1991.

Nowicka-Jeżowa, A., Pieśni czasu śmierci. Studium z historii duchowości XVI-XVIII wieku, Lublin 1992.

Pelc, J., Stowo i obraz na pograniczu literatury i sztuk plastycznych, Cracow 2002.

Pelc, P. and J. Pelc, "Wstęp", in Z. Morsztyn, Emblemata, ed. J. Pelc and P. Pelc, Warsaw 2001.

Pieczyński, M., "Pomiędzy błazeństwem a capriccio. Uwagi o grotesce w późnobarokowej poezji religijnej”, Barok 12 (2005), no. 2, pp. 95-113.

Prejs, M., Poezja późnego baroku. Główne kierunki przemian, Warsaw 1989.

Słomak, I., "Ciało a (nie tylko ignacjańskie) ćwiczenia duchowne. Święty Jan od Krzyża - święty Ignacy Loyola - ojciec Hilarion od Najświętszego Sakramentu", Anthropos 10-11 (2008).

Słomak, I., "Wojsko serdecznych afektów Hieronima Falęckiego - z problematyki edycji, poetyki i recepcji, in Sarmackie theatrum V. Między księgami, ed. M. Barłowska and M. Walińska, Katowice 2012.

Sokolski, J., "Certamen spirituale. Staropolskie poematy alegoryczne o wojnie duchownej”, Prace Literackie 24 (1983), pp. 45-84.

Tazbir, J., Polskie przedmurze chrześcijańskiej Europy. Mity a rzeczywistość historyczna, Warsaw 1987.

Tazbir, J., Polska przedmurzem Europy, Warsaw 2004.

Wanat, B.J., OCD, "Bibliografia świętej Teresy od Jezusa w Polsce", in Otrzymałam ducha madrości. Księga pamiątkowa z okazji ogłoszenia świętej Teresy od Jezusa Doktorem Kościoła Powszechnego, ed. O. Filek, Cracow 1972.

Wanat, B.J., OCD, Drukarnia Karmelu Fortecy N.M.P. w Berdyczowie. Działalność wydawnicza i poligraficzna karmelitów bosych w Berdyczowie na Ukrainie, Cracow 2002.

Wanat, B.J., OCD, Zakon Karmelitów Bosych w Polsce. Klasztory karmelitów $i$ karmelitanek bosych 1605-1975, Cracow 1979.

Wisner, H., Rzeczpospolita Wazów, vol. 2: Wojsko Wielkiego Księstwa Litewskiego, dyplomacja, varia, Warsaw 2004.

Zasady wydawania tekstów staropolskich. Projekt, ed. J. Woronczak, Wrocław 1955.

Zieliński, J., OCD, Herb Karmelu. Historia, symbolika, duchowe przesłanie, Cracow 2001. 